\title{
Stakeholder Consultation and Implementation of Competency Based Education Programme in Public Primary Schools in Kisumu East Sub- County, Kenya
}

\author{
Muga Nerea Anyango ${ }^{1 *}$, Abuya Isaac Odhiambo ${ }^{1}$, Wagude Janet ${ }^{2}$ \\ ${ }^{1}$ University of Nairobi, Nairobi, Kenya \\ ${ }^{2}$ Rongo University, Migori - Rongo Rd, Rongo, Kenya
}

DOI: $10.36348 /$ jaep.2020.v04i03.002 $\quad$ | Received: 04.03.2020 | Accepted: 13.03.2020 | Published: 21.03 .2020

*Corresponding author: Muga Nerea Anyango

\section{Abstract}

Competency Based Education (CBE) programme is being implemented in Kenya's primary and secondary schools. It is believed that competency based education programme will not only make Kenyan students more competitive in the national and global markets, but will also effectively promote competiveness, innovation and will facilitate the acquisition of $21^{\text {st }}$ Century skills among Kenyan students. However, implementation of the competency based education programme has been dogged by controversies and disagreements among various education stakeholders in the country. The controversial issues include perceived limited consultation of stakeholders and the preparedness and readiness of teachers and schools to effectively implement CBE programme. Stakeholders have also raised concern about inadequate teaching and learning resources, overcrowded classrooms, dealing with low ability students and learners. These issues have sparked heated debates and disagreements among stakeholders on teachers' and schools' preparedness to effectively implement competency based education programme. The purpose of this study was to examine the influence of stakeholder consultation process on implementation of competency based education programme in public primary schools in Kisumu east Sub- County, Kenya. Descriptive research design was used. The target population was 1242 consisting of lower grade teachers, head teachers and member of parents' associations from 46 public primary schools in Kisumu East Sub County. A sample size of 291 was computed using Krecjie and Morgan [1]. Data was collected using a self-administered questionnaire. Simple random and stratified sampling procedures were used. Descriptive and inferential statistics were computed using SPSS. Descriptive statistics included frequencies, percentages, means and standard deviations; while inferential statistics included Pearson's correlation(r), co-efficient of determination $\left(\mathrm{R}^{2}\right)$, Anova Test $(\mathrm{p}$ value) and Beta coefficients $(\beta)$. There was significant positive relationship between stakeholder consultation process and implementation of CBE programme in public primary schools. It is recommended that the Ministry of Education and other education policy advisors should strengthen consultations with all the stakeholders to ensure effective and sustainable implementation of CBE programme in the country.

Keywords: Competency Based Education (CBE), stakeholders, Descriptive, SPSS.

Copyright @ 2020: This is an open-access article distributed under the terms of the Creative Commons Attribution license which permits unrestricted use, distribution, and reproduction in any medium for non-commercial use (NonCommercial, or CC-BY-NC) provided the original author and sources are credited.

\section{INTRODUCTION}

Competency Based Education (CBE) programme is being implemented in Kenya's primary and secondary schools. It is believed that competency based education programme will not only make Kenyan students more competitive in the national and global markets, but will also effectively promote competiveness, innovation and will facilitate the acquisition of $21^{\text {st }}$ Century skills among Kenyan students. However, implementation of the competency based education programme has been dogged by controversies and disagreements among various education stakeholders in the country. The controversial issues include perceived limited consultation of stakeholders and the preparedness and readiness of teachers and schools to effectively implement CBE programme. Stakeholders have also raised concern about inadequate teaching and learning resources, overcrowded classrooms, dealing with low ability students and learners. These issues have sparked heated debates and disagreements among stakeholders on teachers' and schools' preparedness to effectively implement competency based education programme. Implementation of Competency Based Education Programmes. 
Competency based education in Kenya has been designed to develop core competencies like communication and collaboration, critical thinking and problem solving, imagination and creativity, citizenship, learning to learn, self-efficacy and digital literacy at the end of the education cycle as learners are expected to take two years in preprimary, six in primary school, three in junior secondary school, three in senior secondary school and three at the University level, Knut [2]. The implementation of the programme has been faced by a number of challenges from inadequate preparations, to alleged incompetence of the teachers to handle the new programme and even asses the competencies themselves, design lesson plans to the inadequate engagement of the stakeholders especially teachers and parents, and the fact that in most parts of the world, CBC has been introduced in vocational institutions such as universities and diploma colleges and not in primary or secondary schools [3].

\section{LITERATURE REVIEW}

\section{Competency Based Education Programme}

According to Bristow and Patrick [4], competency education as a concept is used in the context of expected outcomes at the end of a learning experience as well as the methods of assessment used to support the process. Competency based education is focused on what learners need to learn or do rather than what they have to learn. It sets goals as knowledge, skills and behaviour changes that learners should exhibit at the end of a learning experience. CBE is an evolving system that keeps changing depending on the needs of the teacher, the student or the society, Butova [5]. According to Ford [6], CBE was first implemented in the US teacher education and gained momentum with the enactment of educate America act in 1994 and the subsequent formation of a twenty-eight-person board to come up with the implementation of CBE Voorhees [7]. As Bristow and Patrick [4] further notes a summit held in the US in 2011 proposed a design of CBE where Students will advance to the next level upon mastery of competencies and skills which were to be explicit, measurable as well as transferable. The learning objective, it was proposed, was to empower students and the assessment to be meaningful and positive to the learning experience for the students. The students were to receive timely and differentiated support based on their individual learning needs. The learning outcomes were to emphasize competencies that include application and creation of knowledge, along with the development of important skills and dispositions. Several states in the US have adopted this design while others are in the process. Students undergoing CBE in the US receive a deeply personalized education that offers timely support to keep them engaged all the time and keep them on track to college and career possibilities, Bristow and Patrick [4].
In the US however, according to Ford [8] CBE has been dismissed as an uncoordinated movement that has become an American education fad, and that its main aim, the development and transfer of competency in specific disciplines does not lead to specific workplace skills. Ford [8] continues to argue that there is always a gap between the competencies learnt in secondary schools and that which are learnt in postsecondary, hence lack of continuity. There is also concern about assessment of these competencies, which is viewed as prescriptive and reductionist, Voorhees [7], for instance if a proposed competency cannot be described unambiguously and measurable, then it probably is not a competency, Voorhees [7], hence competencies could become fewer and specific. Another concern raised by Voorhees [7], is that CBE may lead to the demise of postsecondary school education as we know it as some of the skills that are to be certified by the CBE movement are not provided by most hitherto postsecondary institutions. Ford [8] also lists some other challenges that implementation of CBE especially in post-secondary institutions continue to face in the US, such as developing of institutional infrastructure, developing collaboration and teamwork among the institutions and their stakeholders, aligning teaching, learning and assessment to the expected outcomes and to the mission and vision of the institution and displacement or change of traditional roles of existing departments and faculties.

According to Bristow and Patrick [4], Finland's education is the best in the world with its emphasis on a central objective of providing all citizens with equal opportunities, resulting into the enhancement of individual potential in most children in Finland. Finland's core curriculum has shifted from a centralized system emphasizing external testing to a localized one where teachers design their own curricula in line with the national standards, defining overall educational goals for their schools, assuming responsibility for their own student assessment, school improvement and selfassessment. There is a strong societal trust in the schools and teachers charged with carrying out these responsibilities. It is a belief that Finland's success is because they have empowered and prepared their teachers and the fact that the teachers are selected from the top ten percent of high school graduates, however OECD [9], views the selection of teachers from high achievers as a problem since teaching can lose its allure among the young.

It is also argued that leaving control of the curricula and assessment in the hands of the teachers may reduce consistency. OECD [9] continues to wonder if it is possible for the ministry to come back and gain control of the system again. Basing $\mathrm{CBE}$ on trust, OECD [9] continues, cannot be legislated as trust cannot pass the legal test and that students, even though CBE assumes to achieve equality, cannot be equal as each is different in their own ways. OECD [9], argues 
that the system of dividing up secondary schools into academic and vocational units as is done in Finland, is a concern and wonders if the conventional comprehensive education where learners learn the same things is not the best, after all and even wonders if students from the two different units are really that different in their competencies or abilities. There is also the fear that the academic oriented units might attract few students because of the belief that vocational education is more flexible and less demanding.

In New Zealand, teachers have been given the autonomy in the instruction and assessment of learners. It is also characterized by teacher teamwork, students' self-evaluation and freedom to air their concerns and interests as well as a national standard that regulates all these under the ministry of education, Bristow and Patrick [4]. These national standards provide a clear and concise statement of what teachers are expected to know and do, and requires every school to have skilled school leaders to supervise the system and offer tools and training opportunities for the teachers. There is also teacher peer review of lesson plans and assessment tools and lesson observation by the senior staff observations and reporting of data about learners by every school to the national standards office, Bristow and Patrick [4]. Fastier [10] note that the main challenge of CBE in New Zealand is the lack of uniformity as the teachers have freedom to enhance their systems of instruction and assessment, making its implementation from one school to the next different.

Mulenga and Kabombwe [11] notes that in Africa, countries such as, South Africa, Ghana, Kenya, Tanzania, Mozambique and Rwanda have adopted CBE. They also note that all of them seem to have a common element that drove them towards implementation of CBE. It is believed that their prevailing education systems was not responding to the developmental needs of these countries as the learners graduated from school with a lack of appropriate skills and applicable knowledge at the work place, Mulenga and Kabombwe [11].

In South Africa, competency-based curriculum was introduced to address the problem of rampant unemployment among the youth as well as reduce the inequalities that existed across the races as regards the acquisition of skills, Fastier [10]. The South African CBE was designed around learner centered teaching and learning strategies, assessment of these competencies which were designed and supposed to be applicable in real world, KNUT [12]. Critics have accused the programme of emphasizing predictable and measurable learner performance in the classrooms and school situation but these performances cannot be replicated outside the classroom or work situations, Voorhees [7]. Quoting Frances, Matthew and Lesley 2011, child centered teaching and learning methods are often inconclusive since they are not internalized by these countries as the methods are probably shoved down their throats by international agencies, and are not tuned to fit the local situation, KNUT [12].

In Tanzania, Mukunja [13] found out that CBE has been implemented for the past eleven years by the Tanzania institute of education (TIE), the curriculum body. According to Mukunja [13], the aim of CBE in Tanzania, was to ensure that the graduates from schools have developed skills and knowledge that prepare them for life. Mukunja [13] lists challenges that face implementation of CBE in Tanzania, such as lack of in service training for the teachers, inadequate teaching and learning resources, overcrowded classrooms, low ability students and the possibility that learners are not comfortable with learner centered learning approach as advocated by CBC.

In Kenya, it is believed that there was inadequate manpower to spur economic growth with the previous system of education, hence the need for educational reform to help produce graduates who will not only be skilled and relevant, but also be globally competitive. CBC was introduced in 2017 , promoted by the formulation of the sessional paper number 14 of 2012, which required member countries of the East African community (EAC) to harmonize their education system with and which also recommended that $\mathrm{CBE}$ was the preferred education system, Knut [2].

Competencies are fast becoming the focus of education [14]. Bernikova [15] concludes that competency-based approach supposes the development of students' abilities to solve problems in various spheres and activities based on the use of social experience. It is the mastery of universal competencies that can meet the challenges of the time, regardless of the specific field of professional activity. Implementation of competency-based approach makes teachers follow the modern trends and be aware of the technologies available on the market, hence the need to train teachers. Mbarushimana and Kuboja [16] in a descriptive research with a target population of 140 conclude that the implementation of $\mathrm{CBC}$ in Rwanda has improved lives and the quality of those who go through it.

Mulenga and Kabombwe [11], concludes that implementing the competency based curriculum is expensive because of the demands for specialized teaching and learning resources, equipment and infrastructure for the vocational and science based study and since $\mathrm{CBC}$ is learner centered, there is need for retraining the teachers making it the more expensive. The research concludes by calling for the involvement of stakeholders especially donor agencies and NGOS to support the implementation of the programme. They also noted that the budgetary allocation to the education sector has been diminishing further threatening the implementation of CBC. Mulenga et al., [11] also notes 
that, those in servicing teachers for CBC have scanty knowledge about the programme since many have never taught it or practice it hence inadequate training of the teachers.

Kafyulilo, Rugambuka, Ikupa [17], in a study with 78 pre-service teachers as the target population and using questionnaires and structured interview, concluded that, competency based teaching approaches are not well implemented in schools in Tanzania and more efforts need to be devoted in the development of tutors' and principals' understanding of competency based teaching approaches.

Ondimu [18] notes that most of the teachers were well prepared through refresher courses, seminars and workshops, he however states that the teachers needed more retraining in their various subject areas as well as in the preparations of learning and teaching materials such as teaching aids, lesson plans and schemes of work. Using descriptive survey, questionnaires, with structured and unstructured questions and scheduled interviews, the research recommends the inclusion of ICT skills as well in the training process as well as the inclusion of more teachers in the process of the change.

Waweru [3] concludes that most of the teachers were not prepared to implement the programme due to inadequate materials, inadequate training and the incapacity to discern the learners' skills and competencies. Employing descriptive survey and a target population of 336 teachers who filled in questionnaires and were put through a scheduled interview process, he recommends a training framework for the teachers to be developed by the concerned authorities. This is the same conclusion reached by another study, Knut [2] with teachers and Knut officials as the target population that teachers are not prepared for the implementation of the $\mathrm{CBC}$ and that the stakeholders have not been engaged satisfactorily

\section{Stakeholder Consultation Process}

IFC [19] defines stakeholder consultation as a vast term that includes many activities and interactions that take place during a project life cycle, it is an inclusive and continuous process between the project initiators and those likely to be affected and impacted on by the project. Dundee [20] defines stakeholder consultation as the process of interaction between groups of people involved in a project where they are able to raise their concerns and opinions and at the same time include those opinions and concerns in the project decision. Talley, Schneider and Lindquist [21] define stakeholder consultation as the participation of stakeholders in planning or decision-making efforts in order to integrate their knowledge and values with a particular project's more specialized knowledge and purpose. Stakeholder consultation is increasingly becoming important and businesses and financial worlds have recognized the business and reputational risks that come from poor stakeholder relations and have therefore embraced stakeholder consultation, IFC [19].

According to the UNEP \& Accountability [22], the benefits of stakeholder consultation, range from equitable and sustainable development, better management of risks and reputation, pooling of resources to meet the set objectives and understanding an otherwise complex business environment. It helps in learning about each other as it is expected to be a twoway affair, educating and informing the stakeholders at both ends of the spectrum, thereby building trust amongst the stakeholders.

Schumacher and Stybellists [23], agree that stakeholder consultation is important and identifies some of its importance, including helping businesses gain stakeholders' trust, gain support for the organization's decisions, help resolve, reduce and avoid conflicts between stakeholders and help create new relationships among stakeholders and generate a common understanding of problem that face them all. It also brings to light important local knowledge that could be important to the project and increase public knowledge and understanding about the project and other management issues. It can also help the organization realize some of its weaknesses and flaws in its management strategies and help them come up better outcomes and decisions. Schumacher and Stybellists [23] Stakeholder consultation increases responsibility and accountability, contributes to more effective enforcement of rules and regulations by increasing the likelihood of less risks and conflicts. It also enhances acceptance of management policies, decisions and even projects and programmes.

IFC [19] gives some guidelines to on stakeholder consultation, some of which include, engaging early, which helps to build relationships with the stakeholders early enough. They also state that the process should be tailored to the specific organization and project; in fact, it is not a one size fit all situations, as stakeholders are as unique as each project. They even suggest making the local stakeholders part of the management task or function or be institutionalized. Stakeholder consultation should be strategic and prioritized and include aspects such as empowerment, equity, trust and learning and each should be relevant to the needs of the stakeholders. The stakeholder consultation process must be systematic, guided by clear objectives, clear methods of engagement and consider the type of participants and make it highly skilled. Stakeholder consultation however, does come with challenges and there are a few that it brings as being costly, time-consuming, labor-intensive and confrontational. It can also ultimately delay decisionmaking, and create new conflicts or escalate already existing ones. Some of the stakeholders lack knowledge 
especially of the technical aspects of the project making it difficult to engage them and more often than not, most project initiators are not willing to engage stakeholders.

Sturdy, Smith-Merry, and Freeman [4], in their study on stakeholder consultation as a way of social mobilization in social policy and administration on mental health facilities, where they used the action research design and employing direct observation as the research instrument, and concluded that stakeholder consultation is indeed important in the process of implementing a pre-existing policy. Stakeholder consultation, it was also concluded is important in enrolling, orienting and mobilizing the stakeholders to implement already existing policies. In this study the target population consisted of policy makers within the Scottish mental health.

In a study conducted by Biskupek [25], to determine stakeholder power impact on project implementation reached the conclusion that stakeholders to a great extent affect the project in almost all its stages and hence their consultation is important in order to minimize any negative impact on the project and increase the possibility of project success. This implies that even at the implementation stage, stakeholder consultation should be carried out to ensure the effective implementation process. In Biskupek [25] questionnaires were used as the research instrument with the target population consisting of project managers from the South of Poland. The study used descriptive survey as the research design.

Birdthistle, Hynes, and Fleming [5], conducted a study to examine the perceptions and attitudes towards enterprise education at secondary level from a multi-stakeholder perspective and using teachers, principals, pupils and parents as the target population and who filled questionnaires. The study concluded that it is important to create awareness among the parents about new policies and programmes so as to also encourage their children and the need to involve teachers and students to achieve accreditation.

In a study that employed mixed research approach, while employing research method of survey and focus group, to determine stakeholder consultations and opportunities for integrating socio-behavioural factors into the pesticide risk analysis process, discovered that consultations are important to limit the gap between the risk assessment and risk management. The risk assessors need to integrate the views of different disciplines to come up with a comprehensive and effective policy to mitigate the risks, Calliera, Marchis, Sacchettini, and Capri [27]. In another study by Schettino, Calliera, Marchis, Lamastra and Capri [28], to determine how consultation process influences the development of training and awareness-raising on Sustainable Use of Pesticides. Using electronic questionnaires to ask the areas of priority in a training and advocacy, concluded that consulting of the stakeholders helped identify priority areas in safe use of pesticides.

\section{RESEARCH METHODOLOGY Research Design}

According to Sekaran [29], research design is the way that the required data can be gathered and analyzed to arrive at the intended solution. In this research, the researcher adopted descriptive research design, because it can also help to describe the relationships that exist between the variables as is the case in this study [29].

\section{Target Population}

Target population is the entire group of people or things that the researcher is interested in and has the desired characteristics, Sekaran [29]. In this study, the target population was the 1242 teachers in 46 public primary schools in Kisumu east sub County (see list in appendix 1), consisting of 1150 teachers, 46 head teachers and 46 members of parents' associations.

\section{Sample Size and Sampling Procedures}

According to Sekaran [29], a sample is a subset of the target population that is representative and can be used to make generalization about the entire population.

\section{Sample Size}

Sample size was determined from the Krejcie and Morgan [1], (see appendix 6), as quoted in Sekaran [29] the teachers were 291 while the sample size for the head teachers was 46 and the parents association were 46. For each of the 46 schools the sample size was $291 / 46=6$ teachers per school.

\section{Sampling Procedure}

From the above sample sizes, the sampling procedures for the teachers was stratified sampling method, which according to Sekaran (2003), is often used when differentiated information is required different sample categories in this case the different stakeholders in this study like the teachers, head teachers and parents' association. To arrive at the number per school simple random sampling was used.

\section{Research Instruments}

Research instruments are tools that are used to collect data, Sekaran [29]. There are many ways that data can be collected. In this study, questionnaires and scheduled interviews were used to collect data.

\section{Questionnaires}

A self-questionnaire administered was used. The questionnaire had three sections: A, B and C. Section A sought information on the demographic profile of the respondents. Section B sought information on stakeholder consultation and Section C 
sought information on the implementation of $\mathrm{CBE}$ programme.

\section{Pilot Testing of Instruments}

The instruments were tested and retested in the neighboring Nyando sub County. Pretesting the instrument ensures that the questions are understood by the respondents or that they are not ambiguous and that there are no problems with the wording or measurement. Pretesting involves the use of a small number of respondents to test the appropriateness of the questions and their comprehension. This helps to rectify any inadequacies, in time, before the research process commences, Sekaran [29].

\section{Validity of Instruments}

Validity is when the instruments we have set out to use really test the concept or what we want to test. There are many different types of validity [29]. For this research, content validity which according to Sekaran [29] is the type that measure how adequate the set of items like questions to explain the concept, was used. This in this case was verified by the supervisors.

\section{Reliability of Instruments}

Reliability is the measure of goodness or lack of error the instruments are. It is a system where the outcome of a test remains consistent over time. The results are stable and consistent [29]. Reliability can be tested through test and retest, and according to Sekaran 2003 [29], this can be done within a period of several weeks to six months. In this case, because of shortage of time it has to be done in a couple of weeks. Reliability in research is influenced by random error, as random errors increase, reliability decreases. Errors may arise from inaccurate coding and ambiguous instructions to the respondents. The raw data obtained by the instrument was converted to numerical codes representing the measurement of the variables. This coding facilitated the determination of reliability The Cronbach co-efficient Alpha was then computed to determine how the variables will correlate among themselves. Cronbach's Alpha is the general formula of the Kunder Richardson (K-R) 20 [30]. The K-R 20 formula is as follows: KR20 $=(\mathrm{K})(\mathrm{S} 2-\Sigma \mathrm{s} 2) /(\mathrm{S} 2)(\mathrm{K}-1)$ Where; KR20 = Reliability coefficient of internal consistency, $K=$ Number of items used to measure the concept, S2 = Variance of all scores, s2 =Variance of individual items. According to Sekaran (2003), the closer the reliability coefficient gets to 1.0 , the better. In general, reliabilities less than 0.60 are considered to be poor, those in the 0.70 range, acceptable, and those over 0.80 good.

\section{Data Collection Procedures}

Before the collection of data commences, the researcher requested for permission from the national research body, NACOSTI and acquired an introduction letter from the university. The collection of data was started by a request for permission from the ministry of education, county office to access respective schools. Data collection was done through the administration of a questionnaire. Trained research assistants were used due to the time and distance.

\section{Data Analysis Techniques}

Quantitative data was entered in the statistical packages for social sciences (SPSS). The questionnaire was given unique identifiers before entries were made. Both descriptive and inferential analysis was conducted. Descriptive statistics included frequencies, means, standard deviations and composite means and standard deviations. Inferential statistics included correlation and regression analysis. The inferential statistics was used to determine the relationship between the independent variable, stakeholder consultation processes and the dependent variable, implementation of competency based education programme.

\section{Ethical Consideration}

The researcher adhered to the law by getting a permit from NACOSTI to be able to conduct the study. The researcher also acquired an introductory letter from the university. At the beginning of the research instruments, the researcher had an introductory letter for each respondent. The respondents were instructed not to indicate their names or any other form of identification on the research instruments as the need for them to remain anonymous is important to the researcher. The respondents were also informed that the information given shall be treated with utmost confidentiality and that the information is only for academic purposes only.

\section{RESULTS}

\section{Questionnaire Return Rate} in Table-1.

The questionnaire return rate was as presented

Table 1; Questionnaire Return Rate

\begin{tabular}{|l|l|l|}
\hline Response & Frequency & Percentage \\
\hline Responded & 276 & $82 \%$ \\
\hline Non Response & 61 & $18 \%$ \\
\hline Total & 337 & $100 \%$ \\
\hline
\end{tabular}

Table-1 presents the rate of questionnaire return from the study of influence of stakeholder consultation process on implementation of competency based education programme in primary schools in Kisumu East Sub-County. A total of 337 questionnaires were self-administered to 291 teachers and 46 parents. From the table a total of $276(82 \%)$ responded and returned the questionnaires representing $82 \%$ of the total sample. There was $18 \%$ (61) non-response. According to Mugenda and Mugenda [31] a return rate of $50 \%$ is adequate for analysis hence the $82 \%$ return rate is more than adequate. There were also $30(65 \%)$ head teachers interviewed against a target of $46(100 \%)$. 


\section{Background Information of Respondents}

The study sought to establish the background information of respondents. The information sought included, gender, age in years of the respondent, the level of education attained as well as the length of service. The findings were as shown in Table-2.

Table-2: Descriptive Statistics of Respondents' Demographic Profile

\begin{tabular}{|l|l|l|}
\hline & Count & Column N \% \\
\hline Gender & & \\
\hline Female & 159 & $55.0 \%$ \\
\hline Male & 123 & $42.6 \%$ \\
\hline Unspecified & 7 & $2.4 \%$ \\
\hline Total & 289 & $100 \%$ \\
\hline Age Bracket & F & \% \\
\hline $20-30$ & 55 & $19.1 \%$ \\
\hline $31-41$ & 154 & $53.5 \%$ \\
\hline $42-52$ & 57 & 19.8 \\
\hline 53 and above & 22 & $7.6 \%$ \\
\hline Total & 288 & $100.0 \%$ \\
\hline Level of Education & F & $\%$ \\
\hline Certificate & 124 & $43.4 \%$ \\
\hline Diploma & 105 & $36.7 \%$ \\
\hline Undergraduate & 44 & $15.4 \%$ \\
\hline Post graduate & 13 & 4.55 \\
\hline Total & 286 & $100.0 \%$ \\
\hline Length of Service in Years of the respondents & F & $\mathbf{\%}$ \\
\hline $0-10$ & 123 & $49.8 \%$ \\
\hline $11-21$ & 79 & $32.0 \%$ \\
\hline $22-32$ & 37 & $15 \%$ \\
\hline 33 and above & 8 & $3.2 \%$ \\
\hline Total & 247 & $100.0 \%$ \\
\hline & & \\
\hline & & \\
\hline & 24.0 \\
\hline
\end{tabular}

Table-2 presents analysis of demographic information of the respondents, including the gender, the age in years, the level education and the length of service of the respondents. The results are as indicated. Out that $55 \%(159 \%)$ of the respondents were female and $42 \%$ (123) of them were males. There were also $2.4 \%$ (7) of the respondents did not specify their gender even though they filled in the rest of the questionnaire. $53.5 \%$ (154) of the respondents were between the ages of $31-41,19.8 \%$ (57) were in the age category of 42-52. In the age bracket of 20-30, the study found that there were $55(19.1 \%)$, while another $22(7.6 \%)$ were in the age group of 53 and above. On the level of education attained by the respondents, the study realized that 124 (43.4\%) were certificate holders, $36.7 \%$ (105) of the respondents had attained diploma level,44 (15.4\%) respondents or were undergraduate holders while another $4.5 \%$ (13) were holders of postgraduate degree level of education. As far as the length of service is concerned, the study sought to establish among teachers only the number of years of service as it was meaningless for the parents to state this. The study found out that $49.8 \%$ (123) of the teachers had served for between 0-10 years, another 79 (32\%)of them, had served for between 11-21 years, while $15.0 \%$ (37) of the teachers had served for between 22-32 years and $8(3.2 \%)$ had served for 33 years and above.

\footnotetext{
Descriptive Analysis of Implementation of Competency Based Education Programme

Implementation of competency based education programme was the dependent variable where the researcher sought to investigate the influence of stakeholder consultation processes on the implementation of competency based education programme.
} 
Muga Nerea Anyango et al; J Adv Educ Philos, March 2020; 4(3): 78-89

Table-3: Descriptive Statistics on Implementation of CBE Programme

\begin{tabular}{|c|c|c|c|c|c|c|c|c|}
\hline & SA & $\mathbf{A}$ & $\mathbf{N}$ & D & SD & Total & mean & SD \\
\hline $\begin{array}{l}\text { ICBEP1-Stakeholder consultation } \\
\text { enhances timely implementation of } \\
\text { CBE programme }\end{array}$ & $\begin{array}{l}158 \\
(54.7 \%)\end{array}$ & $\begin{array}{l}97 \\
(33.6 \%)\end{array}$ & $\begin{array}{l}25 \\
(8.7 \%)\end{array}$ & $\begin{array}{l}94 \\
(1.4 \%)\end{array}$ & $5(1.7 \%)$ & $\begin{array}{l}289 \\
(100 \%)\end{array}$ & 4.38 & 0.838 \\
\hline $\begin{array}{l}\text { ICBEP2- Stakeholder consultation } \\
\text { enhances timely completion of CBE } \\
\text { programme phases }\end{array}$ & $7(2.4 \%)$ & $\begin{array}{l}114 \\
(39.4 \%)\end{array}$ & $\begin{array}{l}77 \\
(26.6 \%)\end{array}$ & $\begin{array}{l}47 \\
(16.3 \%)\end{array}$ & $\begin{array}{l}44 \\
(15.2 \%)\end{array}$ & $\begin{array}{l}289 \\
(100 \%)\end{array}$ & 2.98 & 1.126 \\
\hline $\begin{array}{l}\text { ICBEP3- } \begin{array}{l}\text { Stakeholder } \\
\text { enhances }\end{array} \text { Stakeholder } \\
\text { with CBE programme }\end{array}$ & $\begin{array}{l}138 \\
(47.8 \%)\end{array}$ & $\begin{array}{l}118 \\
(40.8 \%)\end{array}$ & $\begin{array}{l}30 \\
(10.4 \%)\end{array}$ & $2(0.7 \%)$ & $1(0.3 \%)$ & $\begin{array}{l}289 \\
(100 \%)\end{array}$ & 4.35 & .721 \\
\hline $\begin{array}{l}\text { CBEP4- Stakeholder consultation } \\
\text { enhances cost effectiveness of } \mathrm{CBE} \\
\text { programme }\end{array}$ & $\begin{array}{l}83 \\
(28.7 \%)\end{array}$ & $\begin{array}{l}159 \\
(55 \%)\end{array}$ & $\begin{array}{l}29 \\
(10 \%)\end{array}$ & $9(3.1 \%)$ & $9(3.1 \%)$ & $\begin{array}{l}289 \\
(100 \%)\end{array}$ & 4.03 & .891 \\
\hline $\begin{array}{l}\text { ICBEP5- Stakeholder consultation } \\
\text { promotes quality of CBE programme }\end{array}$ & $\begin{array}{l}102 \\
(35.3 \%)\end{array}$ & $\begin{array}{l}136 \\
(47.1 \%)\end{array}$ & $\begin{array}{l}37 \\
(12.8 \%)\end{array}$ & $\begin{array}{l}10 \\
(3.5 \%)\end{array}$ & $4(1.4 \%)$ & $\begin{array}{l}289 \\
(100 \%)\end{array}$ & 4.11 & .856 \\
\hline & & & & & & Composite & 3.952 & 0.9046 \\
\hline
\end{tabular}

Table- 3 presents the descriptive analysis of the dependent variable, implementation of competency based education programme. ICBEP1 sought information from the respondents on the extent to which they agree that stakeholder consultation enhances timely implementation of CBE programme. Out of 289 respondents, $158(54.7 \%)$ of the stakeholders strongly agreed and another 97 (33.6\%) agreed that stakeholder consultation enhances timely implementation of CBE programme. $25(8.7 \%)$ of the stakeholders were neutral, $1.7 \%$ (5) stakeholders strongly disagreed with the statement and $4(1.4 \%)$ disagreed with the statement. The mean for the item 4.38 and the standard deviation was 0.838 . The item mean (4.38) is higher than the composite mean (3.97), implying that stakeholder consultation strongly enhances timely implementation of CBE programme.

ICBEP2 sought information from the respondents on the extent to which they agree that stakeholder consultation enhances timely completion of CBE programme phases. Out of 289 respondents, 114 $(39.4 \%)$ of the stakeholders agreed that stakeholder consultation enhances timely completion of $\mathrm{CBE}$ programme phases; $26.6 \%$ (77) of the respondents were neutral about the statement that stakeholder consultation enhances timely completion of $\mathrm{CBE}$ programme phases.16.3 (47) of the respondents disagreed that stakeholder consultation enhances timely completion of CBE programme phases., while another $15.2 \%$ ( 44 ) of the respondents strongly disagreed with the statement and another 7 (2.4) of the respondents strongly agreed with the statement. The mean for the item was 2.98 and the standard deviation was 1.126 . The composite mean is higher than the item individual mean which suggests that stakeholder consultation strongly enhances timely implementation of $\mathrm{CBE}$ programme.

ICBEP3 sought information from the respondents on the extent to which they agree that stakeholder consultation enhances stakeholder satisfaction with CBE programme. Out of 289 respondents, $158(54.7 \%)$ of the stakeholders strongly agreed that stakeholder consultation enhances Stakeholder satisfaction with CBE programme; 97 $(33.6 \%)$ agreed that stakeholder consultation enhances Stakeholder satisfaction with CBE programme. $25(8.7 \%)$ of the stakeholders were neutral, $5(1.7 \%)$ strongly disagreed, while $4(1.3 \%)$ disagreed with the statement. The mean for the item 4.38 and the standard deviation was 0.838 . The item mean (4.38) is higher than the composite mean (3.97), implying that stakeholder consultation enhances stakeholder satisfaction with CBE programme.

CBEP4 sought information from the respondents on the extent to which they agree that stakeholder consultation enhances cost effectiveness of CBE programme. Out of 289 respondents, 159 (55\%) agreed that stakeholder consultation enhances cost effectiveness of CBE programme; $28.7 \%$ (83) strongly agreed that stakeholder consultation enhances cost effectiveness of CBE programme; 29 (10.0\%) were neutral to the statement. $3.1 \%$ (9) strongly disagreed and an equal number $9(3.1 \%)$ disagreed with the statement that stakeholder consultation enhances cost effectiveness of CBE programme. The mean for the item is 4.03 and the standard deviation is 0.891 . The individual item mean (4.03) was higher than the composite mean (3.97) suggesting that majority of the respondents agreed with the statement that stakeholder consultation enhances cost effectiveness of $\mathrm{CBE}$ programme.

ICBEP5 sought information from the respondents on the extent to which they agree that stakeholder consultation promotes quality of $\mathrm{CBE}$ programme. Out of 289 respondents, 136 (47.1\%) agreed that that stakeholder consultation promotes quality of CBE programme; 102 (35.3\%)strongly agreed that that stakeholder consultation promotes quality of CBE programme, 37(12.8\%) were neutral, 10 $(3.5 \%)$ disagreed with the statement that stakeholder consultation promotes quality of CBE programme and $4(1.4 \%)$ strongly agreed with the statement. The mean 
for the item is 4.11 and the standard deviation is 0.856 , suggesting that most of the respondents agreed with the statement that stakeholder consultation promotes quality of CBE programme.
Descriptive Analysis of Stakeholder Consultation on Implementation of CBE Programme

The independent variable in this study was stakeholder consultation. The study sought the perspectives of the respondents on the extent to which they agreed with statement on implementation of CBE programme in public primary schools in the SubCounty.

Table 4: Descriptive Statistics of Stakeholder Consultation on Implementation of CBE Programme

\begin{tabular}{|l|l|l|l|l|l|l|l|l|}
\hline & SA & A & N & D & SD & Total & Mean & Std.dev \\
\hline $\begin{array}{l}\text { Stakeholder consultation enhances project } \\
\text { identification (SCP1) }\end{array}$ & $\begin{array}{l}152 \\
(52.6 \%)\end{array}$ & $\begin{array}{l}100 \\
(34.6 \%)\end{array}$ & $\begin{array}{l}26 \\
(9.0 \%)\end{array}$ & $\begin{array}{l}5 \\
(1.7 \%)\end{array}$ & $\begin{array}{l}6 \\
(2.1 \%)\end{array}$ & $\begin{array}{l}289 \\
(100 \%)\end{array}$ & 4.34 & .872 \\
\hline $\begin{array}{l}\text { Stakeholders understand their responsibilities } \\
\text { better if they are consulted(SCP2) }\end{array}$ & $\begin{array}{l}118 \\
(41.0 \%)\end{array}$ & $\begin{array}{l}131 \\
(45.5 \%)\end{array}$ & $\begin{array}{l}28 \\
(9.7 \%)\end{array}$ & $\begin{array}{l}3 \\
(1.0 \%)\end{array}$ & $\begin{array}{l}8 \\
(2.8 \%)\end{array}$ & $\begin{array}{l}289 \\
(100 \%)\end{array}$ & 4.21 & .871 \\
\hline $\begin{array}{l}\text { Needs of the stakeholder are best identified if } \\
\text { the stakeholders are consulted (SCP3) }\end{array}$ & $\begin{array}{l}134 \\
(46.4 \%)\end{array}$ & $\begin{array}{l}120 \\
(41.5 \%)\end{array}$ & $\begin{array}{l}32(11.1 \\
\%)\end{array}$ & $\begin{array}{l}1 \\
(0.3 \%)\end{array}$ & $\begin{array}{l}2 \\
(0.7 \%)\end{array}$ & $\begin{array}{l}289 \\
(100 \%)\end{array}$ & 4.33 & .739 \\
\hline $\begin{array}{l}\text { There is more awareness about project when } \\
\text { stakeholders are consulted (SCP4) }\end{array}$ & $\begin{array}{l}139 \\
(48.1 \%)\end{array}$ & $\begin{array}{l}111 \\
(38.4 \%)\end{array}$ & $\begin{array}{l}27 \\
(9.3 \%)\end{array}$ & $\begin{array}{l}8 \\
(2.8 \%)\end{array}$ & $\begin{array}{l}4 \\
(1.4 \%)\end{array}$ & $\begin{array}{l}289 \\
(100 \%)\end{array}$ & 4.29 & .853 \\
\hline $\begin{array}{l}\text { Stakeholder consultation enables the } \\
\text { identification of project risks (SCP5) }\end{array}$ & $\begin{array}{l}123 \\
(42.6 \%)\end{array}$ & $\begin{array}{l}112 \\
(38.8 \%)\end{array}$ & $\begin{array}{l}39 \\
(13.5 \%)\end{array}$ & $\begin{array}{l}10 \\
(3.5 \%)\end{array}$ & $\begin{array}{l}5 \\
(1.7 \%)\end{array}$ & $\begin{array}{l}289 \\
(100 \%)\end{array}$ & 4.17 & .910 \\
\hline Composite mean & & & & & & & $\mathbf{4 . 2 6 8}$ & $\mathbf{0 . 8 5 2 4}$ \\
\hline
\end{tabular}

Table-4 presents descriptive statistics of stakeholder consultation on implementation of CBE programme. In SCP1 the researcher was to investigate the extent to which stakeholder consultation process influences programme identification in the implementation of competency based education programme, majority of the stakeholders, $52.6 \%$ (152) of them strongly agreed while 100 (34\%) agreed that stakeholder consultation process enhances identification of appropriate programme. There were 26 (9.0\%) answered neutral to the statement.6 (2.1\%) strongly disagreed while another $5(1.7 \%)$ disagreed with the statement. The mean for the item is 4.34 and the standard deviation is 0.872 . The composite mean (4.27) is lower than the individual mean of item SCP1 (4.34) implying that there is a positive significant influence between stakeholder consultation processes and identification of implementation of CBE.

On SCP2 which was to investigate the extent to which stakeholder consultation process influences the understanding of stakeholder responsibilities in the implementation competency based education, $45.5 \%$ (131) of the respondents agreed with the assertion and another $41.0 \%$ (118) strongly agreed consultation influenced understanding of responsibilities.28( 9.7\%) of the stakeholders were neutral and another $2.8 \%$ (8) stakeholders strongly disagreed with the statement while $3(1.0 \%)$ disagreed with the statement. The mean for the item is 4.21 and the standard deviation is 0.871 . The composite mean (4.27) was higher than the SCP2 mean (4.21) suggesting that there is no positive significant influence of stakeholder consultation process on understanding stakeholder responsibilities in implementation of CBE programme.
SCP3 was the third item which was to investigate the extent to which stakeholder consultation process influences the identification of stakeholder needs in the implementation of CBE programme, the responses were, $46.4 \%$ (134) of the stakeholders strongly agreed and another $41.5 \%$ (120) agreed that if they are consulted then their needs would be best identified in the implementation of the competency based education programme. $32(11.1 \%)$ stakeholders remained neutral, while $2(0.7 \%)$ strongly disagreed with thestatement. $0.3 \%$ (1) stakeholder disagreed with the statement. The mean for the item is 4.33 and the standard deviation is 0.739 . The mean for item SCP3 (4.33) is higher than the composite mean (4.27) suggesting that there is a positive significant influence of stakeholder consultation process and stakeholder needs identification in the implementation of CBE programme.

In the SCP4 item, the researcher sought to investigate the extent to which stakeholder consultation process influences the creation of awareness in implementation competency based education programme among the stakeholders, it was realized from the study that $139(48.1 \%)$ of the respondents strongly agreed that consultation process increases awareness about the programme. Another 38.4\% (120) of them agreed that there is more awareness about the programme if they are consulted. $27(9.3 \%)$ of the stakeholders were neutral while8 $(2.8 \%)$ agreed and another $4(1.4 \%)$ disagreed. The mean for the item is 4.29 and the standard deviation is 0.853 . The mean for item SCP4 (4.29) is higher than the composite mean (4.27) suggesting that there is a positive significant influence of stakeholder consultation process on creation of awareness among stakeholders in the implementation of CBE programme. 
In SCP5, the researcher investigated the extent stakeholder consultation influences programme risk identification in the implementation of CBE programme,42.6\% (123) stakeholders, the majority of the stakeholders strongly agreed that if they are consulted then they can be able to identify risks that might arise from the implementation of competency based education programme, $38.8 \%$ (112) of the stakeholders agreed that risks can be identified with stakeholder consultation, another $13.5 \%$ (39) of the respondents were neutral while 3.5 (10) disagreed and $1.7 \%$ (5) stakeholders strongly disagreed. The mean for the item is 4.17 and the standard deviation is 0.910 . The composite mean (4.27) is higher than the mean of item SCP5 (4.17) suggesting there is no positive significant influence of stakeholder consultation process on risk identification in the implementation of $\mathrm{CBE}$ programme.

The overall conclusion is therefore that since the composite mean is, (4.268), majority of the respondents strongly agreed with the statement that stakeholder consultation processes influences the implementation of competency based education programme.

\section{Correlation Analysis}

Pearson product moment correlation coefficient was used to establish the existence or nonexistence of significant relationship as well the degree or strength of association between stakeholder consultation and implementation of CBE programme, based on the perspectives of research participants.

Table-5: Pearson Correlation

\begin{tabular}{|l|l|l|l|}
\hline \multicolumn{2}{|l|}{} & $\begin{array}{l}\text { Stakeholders } \\
\text { Consultation }\end{array}$ & $\begin{array}{l}\text { Implementation of CBE } \\
\text { Programme }\end{array}$ \\
\hline Stakeholders Consultation & Pearson Correlation & 1 & $.118^{* *}$ \\
\cline { 2 - 4 } & Sig. (2-tailed) & & .000 \\
\cline { 2 - 4 } & $\mathrm{N}$ & 289 & 289 \\
\hline $\begin{array}{l}\text { Implementation of CBE } \\
\text { Programme }\end{array}$ & Pearson Correlation & $.118^{* *}$ & 1 \\
\cline { 2 - 4 } & Sig. (2-tailed) & .000 & \\
\cline { 2 - 3 } & $\mathrm{N}$ & 289 & 289 \\
\hline \multirow{2}{*}{$*$. Correlation is significant at the 0.01 level (2-tailed). } & \\
\hline
\end{tabular}

Table-5 presents Pearson correlations statistics on stakeholder consultation and implementation of CBE programme. The analysis shows a strong correlation between stakeholder consultation and implementation of CBE programme with $\mathrm{r}=0.118 \mathrm{p}<0.01$. The findings showed that there is statistical significant relationship between stakeholder consultation and implementation of CBE programme The findings are consistent with the findings of studies reviewed under literature review that found significant relationship between stakeholder consultation and implementation of CBE programme $[25,28]$.

\section{Regression Analysis}

To find the amount of variation in implementation of CBE programme, which explains its association with stakeholder consultation, the coefficient of determination $\left(\mathrm{R}^{2}\right)$, analysis of variance and regression coefficients were computed. The coefficients were also used to help in understanding or explaining the amount of variation in the implementation of CBE programme.

Table-6: Model Summary Table

\begin{tabular}{|l|l|l|l|l|}
\hline Model & R & R Square & Adjusted R Square & Std. Error of the Estimate \\
\hline 1 & $.272^{\mathrm{a}}$ & .074 & .070 & .39540 \\
\hline \multicolumn{4}{|c|}{ a. Predictors: (Constant), Stakeholder Consultation. } \\
\hline
\end{tabular}

To find out the amount of variation in implementation of CBE programme which explains its relationship with Stakeholder consultation, the coefficient of determination $\left(\mathrm{R}^{2}\right)$ was computed. The coefficient was also computed to help in understanding or explaining the amount of variation in implementation of CBE programme. Table-7 is the model summary of Stakeholder consultation and Implementation of CBE programme the above model summary table indicates that there is a positive multiple correlation coefficient $(\mathrm{R}=0.272)$ implementation of $\mathrm{CBE}$ programme and stakeholder consultation and those predicted by the regression model. In addition, the coefficient of determination $\left(\mathrm{R}^{2}=74 \%\right)$ suggests that the amount of variance in implementation of $\mathrm{CBE}$ programme is explained by the stakeholder consultation as per the perspective of all the research participants in the study. The results of this model are consistent with the findings of other studies that found significant relationships between stakeholder consultation and implementation of CBE programme [25, 28]. 
Table-7: Analysis of Variance

\begin{tabular}{|c|c|c|c|c|c|c|}
\hline \multicolumn{2}{|c|}{ Model } & Sum of Squares & df & Mean Square & $\mathbf{F}$ & Sig. \\
\hline \multirow[t]{3}{*}{1} & Regression & 3.198 & 1 & 3.198 & 20.453 & $.000^{\mathrm{b}}$ \\
\hline & Residual & 40.024 & 287 & .156 & & \\
\hline & Total & 43.221 & 288 & & & \\
\hline \multicolumn{7}{|c|}{ a. Dependent Variable: Delivery of ASRHS } \\
\hline \multicolumn{7}{|c|}{ b. Predictors: (Constant), Stakeholder Consultation } \\
\hline
\end{tabular}

The study sought to find out whether the regression model is best fit for predicting Implementation of CBE programme through use of Fstatistics from the ANOVA output. The results are as per table 4.11. According to the results in table 4.11 (F $(5,287)=20.453$ is significant at $\mathrm{P}$ value $<0.05$ implying that the regression model results in significantly better prediction of implementation of CBE programmes. The results are consistent with the findings of other studies that found significant relationships between stakeholder consultation and implementation of CBE programme. The findings are consistent with studies reviewed under literature review $[25,28]$.

Table-8: Regression Coefficients

\begin{tabular}{|l|l|l|l|l|l|}
\hline & \multicolumn{2}{|l|}{ Unstandardized Coefficients } & Standardized coefficients & \multicolumn{2}{l|}{} \\
\hline Model & B & Std. error & Beta & t & Sig. \\
\hline 1 (constant) & 3.663 & .154 & & 23.780 & .000 \\
\hline Stakeholder consultation & .072 & .036 & .118 & 2.013 & .045 \\
\hline
\end{tabular}

a. Dependent Variable: Implementation of CBE programme

From the results, the analysis returns b coefficient constant of 3.663 and predictive variable of 0.72 . This means that a 1-point increase on stakeholder consultation corresponds to 0.72 points increase on the implementation of CBE programme. Hence we can compute the dependent variable through the formula; Dependent $=3.663+(0.72 \times$ stakeholder consultation $)$. Since all $\beta$ coefficients are positive values, it is sensible to conclude that higher values of stakeholder consultation values lead to higher values of the implementation of CBE programme. Furthermore, all the coefficients have a significance of .000 , which is less than 0.05 , indicating that all the $b$ coefficients are statistically significant. The findings are consistent with the findings of studies reviewed under literature review that found that increased stakeholder consultation leads to implementation of CBE programme [25, 28].

\section{DISCUSSION, CONCLUSIONS AND RECOMMENDATION}

The study objective was to investigate the influence of stakeholder consultation process on implementation of competency based education programme in public primary schools in Kisumu east Sub County. The independent variable was stakeholder consultation process which was defined as process which includes stakeholder identification, stakeholder responsibilities; stakeholder needs identification, stakeholder awareness and stakeholder risk identification. According to the findings, majority of the respondents agreed that stakeholder consultation processes has a positive significant influence on implementations of competency based education programme.it is therefore important for competency based education programme implementers to consider engaging the stakeholders in the process, in this case, teachers and the parents. On the influence of stakeholder consultation processes, the stakeholders strongly agreed that it affects the implementation of CBE even from the inferential statistics; it was the only independent variable that showed a significant and positive relationship with the dependent variable and the hypothesis for this objective was rejected. It is recommended that the Ministry of Education and other education policy advisors should strengthen consultations with all the stakeholders to ensure effective and sustainable implementation of $\mathrm{CBE}$ programme in the country.

\section{REFERENCES}

1. Krejcie, R. V., \& Morgan, D. W. (1970). Educational and psychological measurement. New York: Minnisota University.

2. Lie, K. A. (2019). An introduction to reservoir simulation using MATLAB/GNU Octave: User guide for the MATLAB Reservoir Simulation Toolbox (MRST). Cambridge University Press.

3. Waweru, N. M., \& Prot, N. P. (2018). Corporate governance compliance and accrual earnings management in eastern Africa. Managerial Auditing Journal.

4. Patrick, S., \& Bristow, S. F. (2014). An International Study in Competency Education: Postcards from Abroad.

5. Butova, Y. (2015). The history of development of competency-based education. European Scientific Journal.

6. Ford, M. (2015). Rise of the Robots: Technology and the Threat of a Jobless Future. Basic Books.

7. Voorhees, R. A. (2001). Competency-Based Learning Models: A Necessary Future. 
8. Ford, R., \& Goodwin, M. J. (2014). Revolt on the right: Explaining support for the radical right in Britain. Routledge.

9. Organisation for Economic Co-operation and Development (OECD). (2010). Education at a glance 2010: OECD indicators. Paris: OECD.

10. Fastier, M. (2013). Curriculum development in New Zealand: New directions, opportunities and challenges for school geography. Review of International Geographical Education Online, 3(3), 241-252.

11. Mulenga, I. M., \& Kabombwe, Y. M. (2019). A Competency-Based Curriculum for Zambian Primary and Secondary Schools: Learning from theory and some Countries around the World.

12. Kenya National Union of Teachers. (2019). Teacher preparedness for the implementation of the competency-based curriculum in preprimary and lower primary grades in Kenya.

13. Abraham, A., Natraj, U., Karande, A. A., Gulati, A., Murthy, M. R., Murugesan, S., ... \& Savithri, H. S. (2016). Intracellular delivery of antibodies by chimeric Sesbania mosaic virus (SeMV) virus like particles. Scientific reports, 6, 21803.

14. Lee, K. (2014). Competency-based curriculum and curriculum autonomy in the Republic of Korea Geneva, Switzerland, UNESCO International Bureau of Education.

15. Bernikova, O. (2017). Laboratory for Analysis and Modeling of Social Processes, St Petersburg Proceedings of the 8th International MultiConference on Complexity, Informatics and Cybernetics.

16. Mbarushimana, N., \& Kuboja, J. M. (2016). A paradigm shift towards competence-based curriculum: The experience of Rwanda. Saudi Journal of Business and Management Studies, 1(1), 6-17.

17. Kafyulilo, A. C., Rugambuka, I. B., \& Moses, I. (2013). Implementation of Competency Based Teaching in Morogoro Teachers' Training College, Tanzania. Makerere Journal of Higher Education, 4(2), 311-326.

18. Ondimu, S. M. (2018). Teachers' Preparedness for Implementation of the Competency Based Curriculum in Private Pre-schools in Dagoretti North Sub-county, Nairobi City County (Doctoral dissertation, university of nairobi).

19. International Finance Corporation. (2007). Stakeholder consultation: A Good Practice Handbook for Companies Doing Business in Emerging Markets.
20. Kazlauskaite, A., Kondapalli, C., Gourlay, R., Campbell, D. G., Ritorto, M. S., Hofmann, K., ... \& Muqit, M. M. (2014). Parkin is activated by PINK1-dependent phosphorylation of ubiquitin at Ser65. Biochemical Journal, 460(1), 127-141.

21. Talley, J. L., Schneider, J., \& Lindquist, E. (2016). A simplified approach to stakeholder engagement in natural resource management: the Five-Feature Framework. Ecology and Society, 21(4):38.

22. UNEP \& Accountability. (2005). The stakeholders' engagement manual, the practitioners' handbook, 2.

23. Schumacher, J., \& Stybel, N. (2012). Stakeholder Involvement and Participation: A System

Approach Framework For Coastal Research \& Management, Bonus Baltcoast.

24. Sturdy, S., Smith-Merry, J., \& Freeman, R. (2012). Stakeholder Consultation as Social Mobilization: Framing Scottish Mental Health Policy. Social Policy \& Administration, 46(7):823844.

25. Biskupek, A. (2016). The Research of Stakeholder Power Impact on Project Implementation Trends. Economics \& Management / Trendy: Ekonomiky a Managementu, 10(27):9-19.

26. Birdthistle, N., Hynes, B., \& Fleming, P. (2007). Enterprise education programmes in secondary schools in Ireland. Education+ Training.

27. Calliera, M., Marchis, A., Sacchettini, G., \& Capri, E. (2016), Stakeholder consultations and opportunities for integrating socio-behavioral factors into the pesticide risk analysis process Environmental Science and Pollution Research International,23(3):2937-2947.

28. Schettino, G., Calliera, M., Marchis, A., Lamastra, L., \& Capri, E. (2012). The stakeholderconsultation process in developing training and awareness-raising material within the framework of the EU Directive on Sustainable Use of Pesticides: The case of the EU-project BROWSE. Science of the Total Environment, 438, 278-285.

29. Sekaran, U. (2003). Research methods for business, A Skill-Building Approach, Fourth Edition, Southern Illinois University at Carbondale John Wiley \& Sons, Inc.

30. Mugenda, O. M., \& Mugenda, A. G. (1999). Research methods: Quantitative and qualitative approaches. Acts press.

31. Mugenda, O., \& Mugenda, A. G. (2003). Research methods: Quantitative and Qualitative methods. Revised in Nairobi. 